\title{
Fine-scale habitat requirements of the Heidelberg Opal Butterfly (Chrysoritis aureus) in Gauteng and Mpumalanga, South Africa
}

\begin{tabular}{|c|c|}
\hline \multicolumn{2}{|c|}{$\begin{array}{l}\text { Authors: } \\
\text { Rouxdene Deysel }^{1} \\
\text { Willem J. Myburgh }^{2} \text { (D) } \\
\text { Mike D. Panagos }^{2}\end{array}$} \\
\hline \multicolumn{2}{|c|}{$\begin{array}{l}\text { Affiliations: } \\
{ }^{1} \text { Gauteng Department of } \\
\text { Agriculture and Rural } \\
\text { Development, Biodiversity } \\
\text { Management, Scientific } \\
\text { Services Unit, South Africa }\end{array}$} \\
\hline \multicolumn{2}{|c|}{$\begin{array}{l}{ }^{2} \text { Department of Nature } \\
\text { Conservation, Tshwane } \\
\text { University of Technology, } \\
\text { South Africa }\end{array}$} \\
\hline \multicolumn{2}{|c|}{$\begin{array}{l}\text { Corresponding author: } \\
\text { Rouxdene Deysel, } \\
\text { Rouxdene.Deysel@gmail.com }\end{array}$} \\
\hline \multicolumn{2}{|c|}{$\begin{array}{l}\text { Dates: } \\
\text { Received: } 02 \text { May } 2017 \\
\text { Accepted: } 11 \text { Sept. } 2017 \\
\text { Published: } 31 \text { Oct. } 2017\end{array}$} \\
\hline \multicolumn{2}{|c|}{$\begin{array}{l}\text { How to cite this article: } \\
\text { Deysel, R., Myburgh, W.J. \& } \\
\text { Panagos, M.D., 2017, } \\
\text { 'Fine-scale habitat } \\
\text { requirements of the } \\
\text { Heidelberg Opal Butterfly } \\
\text { (Chrysoritis aureus) in } \\
\text { Gauteng and Mpumalanga, } \\
\text { South Africa', Bothalia 47(1), } \\
\text { a2220. https://doi.org/ } \\
\text { 10.4102/abc.v47i1.2220 }\end{array}$} \\
\hline \multicolumn{2}{|c|}{$\begin{array}{l}\text { Copyright: } \\
\text { (C) 2017. The Authors. } \\
\text { Licensee: AOSIS. This } \\
\text { is licensed under the } \\
\text { Creative Commons } \\
\text { Attribution License. }\end{array}$} \\
\hline \multicolumn{2}{|l|}{ Read online: } \\
\hline 口ifrin & $\begin{array}{l}\text { Scan this QR } \\
\text { code with your } \\
\text { smart phone or } \\
\text { mobile device } \\
\text { to read online. }\end{array}$ \\
\hline
\end{tabular}

Background: This study quantified the fine-scale habitat requirements of Chrysoritis aureus, at 11 known habitats in Gauteng and Mpumalanga, South Africa, in order to make habitat management recommendations for this endangered species.

Objectives: The habitats were quantified in terms of plant species composition and structure with reference to their environmental characteristics.

Method: A modified area-based phytosociological approach was used to collect floristic data along with environmental characteristics of habitats occurring on the Witwatersrand and Ventersdorp Geological Systems.

Results: Species recorded were predominantly forbs and graminoids with a slightly higher number of plant species in the habitats of the Ventersdorp Geological System. Few dwarf shrubs and shrubs and very few trees were recorded. A higher number of plant species were recorded during the late growing season on both geological systems. The butterfly food plant Clutia pulchella var. pulchella L. (Euphorbiaceae) was recorded in all the habitats and was dominant in habitats in both geological systems. The occurrence of the food plant is essential for the survival of the butterfly at these habitats.

Conclusion: Monitoring of the C. aureus butterfly populations and of the vegetation structure, species composition and growth forms to determine trends in the vegetation condition after planned fires; regular burning of the habitats in order to maintain suitable vegetation composition and structure; and the monitoring and eradication of alien invader plants are very important management activities to ensure the conservation of $C$. aureus.

\section{Introduction}

Butterflies are well known for their role in the pollination of flowering plants and they often perform unique functions in pollination (Mecenero et al. 2013). Because of the intimate relationship they form with plants in both their larval and adult forms, and because they are easy to sample and identify, butterflies are frequently used as indicators of ecosystem and habitat quality in monitoring programmes (McGeoch et al. 2011; Mecenero et al. 2013). In South Africa, protected areas such as national parks and provincial nature reserves play an important role in preserving butterfly species occurring within their boundaries by conserving their habitats (Henning, Terblanche \& Ball 2009). Numerous studies worldwide have established that the major or only cause of loss or decline of terrestrial insect populations is habitat alteration or destruction (Henning et al. 2009). In South Africa, the most significant threats are invasive alien vegetation, changing fire regimes (either an increase or reduced fire frequency), agricultural activities, urbanisation, plantation forestry, increased grazing and road construction (Henning et al. 2009). Habitat changes result in an absence of conditions (e.g. temperature, $\mathrm{pH}$ and relative humidity), resources and biological interactions (niche requirements) that are required by individuals of a species for their survival. Abiotic conditions may be modified by biotic factors, such as height and density of local vegetation. Quality and persistence of habitat and ability to maintain gene flow are recognised globally as being of primary importance for butterfly conservation (Henning et al. 2009). Detailed analysis of the ecological requirements and resource needs of a threatened species have to be undertaken before effective conservation measures and management can be initiated (Mecenero et al. 2013). The abiotic conditions, vegetation composition and structure of the habitat must also be recorded and analysed to establish the requirements necessary to maintain suitable habitat and microclimate.

The Heidelberg Opal Butterfly, Chrysoritis aureus (Van Son 1966), was first recorded at a site near the R23 road in Heidelberg by C. Barrett and F. Coetzee in 1959 and the range was found to extend 
as far as the ridges north of Greylingstad in Mpumalanga (Roos \& Henning 1998). In the latest Red List assessment of South African butterflies, the endemic C. aureus is listed as endangered (Mecenero et al. 2013). Montane rocky habitat at 1600 m-1800 m with grass- and forb-dominated vegetation, rich in plant species (10-28 species per $25 \mathrm{~m}^{2}$ ) (Bredenkamp \& Van Rooyen 1996; Terblanche, Morgenthal \& Cilliers 2003), with a variety of forbs flowering during the growing season from September to April, is ideal habitat for C. aureus (Roos \& Henning 1999). Flowering forbs are visited by butterflies as a source of nectar. These habitats are found on steep south to southeast-facing mid-slopes of rocky ridges and hills where large rocks with crevices or small cliffs are present to provide shelter and cover for the butterfly larvae (Terblanche et al. 2003). The larval host plant Clutia pulchella var. pulchella L. (Euphorbiaceae) is widely distributed in South Africa (Germishuizen et al. 2006) and is found growing on flat shelves between rock strata.

The life history of C. aureus was briefly described by Roos and Henning (1999). The development of C.aureus is synchronised to the growth cycle of the larval host plant from October to April and the number of individual generations per year is estimated at three (Roos \& Henning 1999). Chrysoritis aureus is localised in all the habitats where it occurs, and these are less than 50 ha in size across rocky slopes and most of the individuals in a colony will, for most of the time, fly within a habitat range of $200 \mathrm{~m}^{2}-400 \mathrm{~m}^{2}$ (Terblanche \& Van Hamburg 2003). Crematogaster ants constantly attend to the larvae and continue to tend to the pupae throughout the winter months. The presence of both the host plant and the associated ant, Crematogaster liengmei Forel, 1894 (Myrmecinae), is essential to the successful completion of the life cycle and therefore survival of C. aureus (Roos \& Henning 1999; Terblanche et al. 2003). There are 11 known habitats where C. aureus has been recorded (Roos \& Henning 1999) of which eight are situated in the Witwatersrand and three are situated in the Ventersdorp Geological Systems.

Various vegetation studies have been conducted in the larger study area where $C$. aureus is found, but the scale of these is not suitable for describing the very limited and relatively small habitats of C. aureus (Coetzee, Bredenkamp \& Van Rooyen 1995; Department of Agriculture and Rural Development 2013; Hoare 2006; Panagos 1999). Terblanche et al. (2003) classified the vegetation and compared habitat characteristics of three $C$. aureus localities at Alice Glöckner Nature Reserve, Suikerbosrand Nature Reserve and Malanskraal farm in February 1999. Although the general vegetation structure in the three localities was found to be similar, there were marked differences in floristic composition between the Alice Glöckner and Suikerbosrand Nature Reserve habitats on the Witwatersrand Geological System and the authors suggested that further detailed studies of vegetation structure in larger sample plots be carried out because vegetation structure is an important factor in the management of these habitats.
This study aimed to quantify the fine-scale floristic composition and vegetation structure of all 11 known habitats of $C$. aureus on the south-facing slopes of the ridges in the Heidelberg, Balfour and Greylingstad areas. The main objective of this article is to describe the floristic (in terms of plant species composition and structure) and environmental characteristics of the C. aureus habitats occurring on the Witwatersrand and Ventersdorp Geological Systems in the early and late growing seasons, and to make recommendations for managing the habitats.

\section{Study area}

Suitable habitat for C. aureus is located on the south-facing slopes of rocky ridges at altitudes ranging from $1600 \mathrm{~m}$ to $1800 \mathrm{~m}$ above sea level near Heidelberg in Gauteng and Balfour and Greylingstad in Mpumalanga (Henning \& Roos 1998; Terblanche et al. 2003) and in the Ib42 and Ib43 Land Types (Land Type Survey Personnel 1985). The Witwatersrand Geological System (habitats found near Heidelberg) consists of quartzite, slate grit and conglomerate with Mispah, Glenrosa, Clovelly and Hutton soils on the crests and midslopes. The Ventersdorp Geological System (habitats found near Balfour and Greylingstad), on the other hand, consists of lava, breccias and tuff with Mispah, Glenrosa, Shortlands, Bonheim, Valsrivier, Rensburg, Avalon and Hutton soil formations (Land Type Survey Personnel 1985). The study area lies within the Andesite Mountain Bushveld (SVcb11) Gold Reef Mountain Bushveld (SVcb9) and Tsakane Clay Grassland (Gm9) (Mucina \& Rutherford 2006).

The mean annual temperature in the study area is $15.6^{\circ} \mathrm{C}-16.4^{\circ} \mathrm{C}$, with mean monthly maximum and minimum temperatures for January and July recorded as $30.8^{\circ} \mathrm{C}$ and $-1.8^{\circ} \mathrm{C}$ respectively (in Krugersdorp) (Mucina \& Rutherford 2006). Rainfall occurs in summer with very dry winters, with the mean annual precipitation (MAP) being $660 \mathrm{~mm}$ (Mucina \& Rutherford 2006). Frost occurs frequently in winter especially in the south but less so on the ridges and hills, with a mean of 34 frost days. Long-term climatic data were obtained for two weather stations in the study area (South African Weather Service 2013). The mean annual rainfall measured at the Johannesburg weather station from 1981 to 2010 was $750 \mathrm{~mm}$. The mean temperature recorded at this station was $16.2^{\circ} \mathrm{C}$. The mean annual rainfall measured at the Secunda weather station from 1984 to 2010 was $737 \mathrm{~mm}$ with the mean temperature recorded as $16.2^{\circ} \mathrm{C}$.

\section{Research method and design Study sites}

Three sample plots were placed in each of the 11 known habitats, parallel to each other and $10 \mathrm{~m}$ apart, thus totalling 33 sample plots with a combined surface area of $3300 \mathrm{~m}^{2}$. A sample plot consisted of a belt transect of $100 \mathrm{~m}^{2}(5 \mathrm{~m} \times 20 \mathrm{~m})$ and all sample plots were placed perpendicular to the slope in order to maximise species variation (Panagos 1999) and to include the terraces. A modified area-based phytosociological approach was used for the vegetation surveys (Barbour et al. 
1999; Braun-Blanquet 1965; Kent \& Coker 2003; Werger 1974). Each sample plot was surveyed twice, coinciding with two of the main flying events of the adult butterflies (Henning \& Roos 1998) from the middle to the end of December 2011 (referred to as the early growing season) and from the beginning to the middle of March 2012 (referred to as the late growing season).

\section{Floristic characteristics}

All the living plant species rooted within the sample plots were identified during the surveys, using field guides (Bromilow 2001; Pooley 2003, 2005; Van Oudtshoorn 2004; Van Wyk \& Malan 1998), or labelled plant specimens were collected for later identification by the National Herbarium of the South African National Biodiversity Institute (SANBI). Species richness is a count of the number of plant species in each sample plot or habitat (Kent \& Coker 2003). A crown cover value or symbol was assigned to each species using the Plant Number Scale (Panagos 1999; Panagos et al. 1998; Westfall \& Panagos 1988), indicating the percentage canopy cover of each species measured as crown diameter and mean spacing between individuals of the same species within a specified area. A growth form (tree, shrub, dwarf shrub, graminoid or forb) was assigned to each species following Westfall et al. (1996).

Dominant plant species (species with a mean canopy cover $>1.5 \%$ ) for the early and late growing seasons were quantified in terms of cover per habitat (Westfall et al. 1982, 1996, 1997). The mean height per species, measured in all the sample plots, was recorded during both surveys as an additional measure of vegetation structure. Notes were made on the phenology (presence of leaves and inflorescences) of all recorded species per growth form in all sample plots during both surveys. All C. pulchella var. pulchella individuals rooted within each sample plot were counted to determine their density per square metre in each habitat.

\section{Environmental characteristics}

The geological information of all habitat localities was obtained using a geological map (2628 East Rand, 1:250 000, Land Type Series 1985), GDARD GIS data and the Land Types Memoir of the East Rand (Land Type Survey Personnel 1985). Soil samples were collected and soil depth was determined (Bredenkamp 1975) in the middle of each sample plot. The soil forms of all sample plots were determined using the soil classification of Macvicar et al. (1991). Clay percentage was determined using the sausage method (Loxton 1966). The amount of surface rock present in each sample plot was estimated as a percentage of the surface area of the sample plot covered by rock (Myburgh 2000). The average size of the rocks present was determined by measuring the rocks and was recorded using the classes of Myburgh (2000). The aspect of all sample plots, measured from the reference corners, was obtained using a compass. The slope was measured in degrees using a handheld clinometer and slope classes are according to the National
Terrain Classification System (Forestry Commission 1996; SAPPI 2004). The terrain consists of various combinations of terrain units making up the landscape and was recorded at each sampling site.

\section{The presence and absence of Chrysoritis aureus}

The presence or absence of the various life stages (egg, larvae, pupae and butterfly) of $C$. aureus was noted at each habitat for both the early and late growing season surveys.

\section{Data analyses}

The floristic data recorded for all sample plots were analysed using the PHYTOTAB-PC computer programme (Westfall et al. 1982, 1996; Westfall, Theron \& Van Rooyen 1997). Species richness per geological system and growth form were tabulated for the butterfly habitats in the early and late growing seasons, as determined by PHYTOTAB-PC. Similarly, the percentage canopy cover per geological system was tabulated for these habitats in both growing seasons. The results for the C. pulchella var. pulchella counts were analysed to illustrate the mean number of host plants recorded per square metre in each geological system.

Dominant plant species (mean canopy cover $>1.5 \%$ as quantified using the PHYTOTAB-PC) for the butterfly habitats, for both growing seasons, were quantified in terms of mean percentage canopy cover per habitat (Westfall et al. 1982, 1996, 1997). The mean plant height of these dominant species was tabulated for each geological system for the early and late growing seasons. Flower presence at the time of the surveys was tabulated for all the dominant graminoids, forbs, dwarf shrubs, shrubs and trees in the C. aureus habitats for both growing seasons.

\section{Results}

\section{Floristic characteristics}

\section{Species richness}

Species recorded in the habitats were predominantly forbs and graminoids. Few dwarf shrubs and shrubs, and only two trees were recorded in the habitats. During the early and late growing seasons, a slightly higher number of plant species was recorded in the habitats in the Ventersdorp Geological System compared to the number recorded in the Witwatersrand Geological System (Table 1). A higher number of species were recorded during the late growing season on both geological systems. No alien invasive trees were recorded in the sample plots or in the habitats of $C$. aureus.

\section{Percentage canopy cover and food plant density}

The cover was mostly ascribed to forb and graminoid species for both the early and late growing seasons. Forb and graminoid cover were greater in the Ventersdorp than in the Witwatersrand Geological System in both seasons (Table 2). Clutia pulchella var. pulchella was recorded at all the habitats in both the early and late growing seasons and densities were very similar for the two geological systems (Table 2). 
TABLE 1: Number of plant species per geological system and number of species per growth form in the Witwatersrand and Ventersdorp Geological Systems in the early and late growing seasons.

\begin{tabular}{|c|c|c|c|c|}
\hline \multirow[t]{2}{*}{ Measurements } & \multicolumn{2}{|c|}{ Witwatersrand Geological System } & \multicolumn{2}{|c|}{ Ventersdorp Geological System } \\
\hline & December 2011 & March 2012 & December 2011 & March 2012 \\
\hline Total no. of sample plots in geological system & 24 & 24 & 9 & 9 \\
\hline Total no. of species in geological system & 141 & 151 & 148 & 155 \\
\hline Species richness (mean number of species per sample plot) & 35 & 41 & 53 & 62 \\
\hline Trees & 1 & 2 & 2 & 2 \\
\hline Shrubs & 7 & 5 & 8 & 12 \\
\hline Dwarf shrubs & 16 & 18 & 21 & 23 \\
\hline Forbs & 82 & 93 & 97 & 106 \\
\hline Graminoids & 41 & 39 & 27 & 21 \\
\hline Total & 147 & 157 & 155 & 164 \\
\hline
\end{tabular}

Source: R. Deysel, Magister Technologiae: Nature Conservation Thesis, 2016

Species richness per growth form per geological system (number of species; some species were recorded in more than one growth form, for example, as a dwarf shrub, shrub and tree)

TABLE 2: Mean percentage canopy cover per growth form, the food plant cover percentage and the density of Clutia pulchella var. pulchella plants per square metre per geological system in the early and late growing seasons.

\begin{tabular}{|c|c|c|c|c|}
\hline \multirow[t]{2}{*}{ Measurements } & \multicolumn{2}{|c|}{$\begin{array}{l}\text { Witwatersrand Geological System Mean } \\
\text { percentage canopy cover }\end{array}$} & \multicolumn{2}{|c|}{$\begin{array}{l}\text { Ventersdorp Geological System Mean percentage } \\
\text { canopy cover }\end{array}$} \\
\hline & 2011 & 2012 & 2011 & 2012 \\
\hline Tree & 0.00 & 0.00 & 0.06 & 0.07 \\
\hline Dwarf shrub & 1.77 & 3.20 & 4.37 & 4.66 \\
\hline Forb & 5.50 & 5.18 & 7.41 & 13.16 \\
\hline Graminoid & 11.45 & 29.63 & 21.01 & 49.69 \\
\hline Clutia pulchella var. pulchella cover contribution percentage & 0.90 & 1.81 & 1.64 & 1.65 \\
\hline Density $\left(\mathrm{m}^{2}\right)$ of Clutia pulchella var. pulchella & 0.50 & 0.50 & 0.50 & 0.60 \\
\hline
\end{tabular}

Source: R. Deysel, Magister Technologiae: Nature Conservation Thesis, 2016

\section{Dominant plant species}

The graminoids Themeda triandra Forssk. and Setaria nigrirostris (Nees) T. Durand \& Schinz were the dominant species recorded in the habitats of the Ventersdorp Geological System in the early and late growing seasons (Tables 3 and 4). In the Witwatersrand Geological System, Aristida transvaalensis Henrard was the dominant graminoid recorded in both the early and late growing seasons (Tables 3 and 4 ).

Clutia pulchella var. pulchella was recorded in all sampled habitats in the early and late growing seasons, but was only considered a dominant forb in four habitats in the Witwatersrand and two habitats in the Ventersdorp Geological Systems in the late growing season (Table 4). Various other forb species were dominant in the Witwatersrand and the Ventersdorp Geological Systems in the early and late growing seasons. Very few dwarf shrubs and shrubs were recorded as dominant in either of the geological systems (Tables 3 and 4).

\section{Dominant plant species height and inflorescence}

In both growing seasons, the mean height for the dominant graminoids was similar in the two geological systems and the dominant forbs in the Witwatersrand Geological System had a greater height (Tables 3 and 4). Dwarf shrubs were only recorded in the Ventersdorp Geological System in the early season, and these had a mean height of $905 \mathrm{~mm}$. In the late growing season, the mean height of dwarf shrubs varied between $567 \mathrm{~mm}$ and $910 \mathrm{~mm}$ and the mean height of shrubs was $1400 \mathrm{~mm}$ (Table 4).
Various dominant graminoids had flowers present during the early and late growing seasons in the habitats of both geological systems (Tables 3 and 4). The dominant forbs with inflorescences present included Clutia pulchella var. pulchella in both geological systems. No shrubs were flowering at the time of sampling.

\section{Environmental characteristics}

The Witwatersrand and Ventersdorp Geological Systems differed in soil type, soil texture and clay percentage, rock size, land types, slope and terrain units (Table 5).

\section{The presence and absence of the Heidelberg Opal Butterfly}

Chrysoritis aureus was recorded in both the Witwatersrand and Ventersdorp Geological Systems during the early growing season (six and two habitats, repectively), but only at five habitats in the Witawatersrand Geological System during the late growing season. The host ant was observed in 10 of the 11 habitats in the early growing season and in seven habitats in the late growing season.

\section{Discussion}

\section{Floristic characteristics}

Typical C. aureus habitats are characterised by an optimal vegetation structure, species composition and environmental parameters within each of the geological systems. Although there are different plant species characteristics of the habitats on the two geological systems, as was also observed by 
TABLE 3: Dominant plant species (mean percentage canopy cover), mean height $(\mathrm{mm})$ and number of habitats with flowers present in the Witwatersrand and Ventersdorp Geological Systems in the early growing season.

\begin{tabular}{|c|c|c|c|c|c|c|c|}
\hline \multirow[t]{2}{*}{ Growth forms } & \multirow[t]{2}{*}{ Species } & \multicolumn{3}{|c|}{ Witwatersrand Geological System } & \multicolumn{3}{|c|}{ Ventersdorp Geological System } \\
\hline & & Canopy cover (\%) & Plant height $(\mathrm{mm})$ & Flower presence & Canopy cover (\%) & Plant height (mm) & Flower presence \\
\hline \multirow[t]{4}{*}{ Graminoid } & Themeda triandra & - & - & - & 8.92 & 123 & 3 \\
\hline & Cymbopogon nardus & - & - & - & 2.35 & 323 & 2 \\
\hline & Aristida transvaalensis & 6.66 & 189 & 8 & - & - & - \\
\hline & Setaria nigrirostris & - & - & - & 7.71 & 157 & 3 \\
\hline \multirow[t]{3}{*}{ Forb } & Clutia pulchella var. pulchella & - & - & - & 1.64 & 279 & 3 \\
\hline & Pteridium aquilinum sub.sp. aquilinum & 3.44 & 588 & - & - & - & - \\
\hline & Berkheya setifera & - & - & - & 1.88 & 189 & 3 \\
\hline Dwarf shrub & Searsia pyroides var. gracilis var. gracilis & - & - & - & 1.97 & 905 & 2 \\
\hline
\end{tabular}

Source: R. Deysel, Magister Technologiae: Nature Conservation Thesis, 2016

TABLE 4: Dominant plant species (mean percentage canopy cover), mean height ( $\mathrm{mm}$ ) and number of habitats with flowers present in the Witwatersrand and Ventersdorp Geological Systems in the late growing season.

\begin{tabular}{|c|c|c|c|c|c|c|c|}
\hline \multirow[t]{2}{*}{ Growth form } & \multirow[t]{2}{*}{ Species } & \multicolumn{3}{|c|}{ Witwatersrand Geological System } & \multicolumn{3}{|c|}{ Ventersdorp Geological System } \\
\hline & & Canopy cover (\%) & Plant height (mm) & Flower presence & Canopy cover (\%) & Plant height $(\mathrm{mm})$ & Flower presence \\
\hline \multirow[t]{6}{*}{ Graminoid } & Themeda triandra & - & - & - & 17.60 & 582 & 3 \\
\hline & Cymbopogon nardus & 3.20 & 972 & 7 & - & - & - \\
\hline & Aristida transvaalensis & 13.90 & 434 & 8 & - & - & - \\
\hline & Loudetia simplex & 3.10 & 572 & 8 & - & - & - \\
\hline & Setaria nigrirostris & - & - & - & 17.30 & 433 & 3 \\
\hline & Hyparrhenia hirta & - & - & - & 6.70 & 1050 & 3 \\
\hline \multirow[t]{4}{*}{ Forb } & Clutia pulchella var. pulchella & 1.80 & 400 & 8 & 1.70 & 331 & 2 \\
\hline & Pteridium aquilinum sub.sp. aquilinum & 1.90 & 602 & - & - & - & - \\
\hline & Berkheya setifera & - & - & - & 3.90 & 175 & - \\
\hline & Hilliardiella aristata & - & - & - & 3.00 & 258 & - \\
\hline \multirow[t]{2}{*}{ Dwarf shrub } & Searsia magalismontana sub.sp. coddii & 2.40 & 147 & & & & - \\
\hline & Athrixia elata & - & - & - & 2.00 & 567 & - \\
\hline Shrub & Leucosidea sericea & - & - & - & 1.90 & 1400 & - \\
\hline
\end{tabular}

Source: R. Deysel, Magister Technologiae: Nature Conservation Thesis, 2016

TABLE 5: Environmental characteristics of the habitats of the in the Witwatersrand and Ventersdorp Geological Systems.

\begin{tabular}{lcc}
\hline $\begin{array}{l}\text { Environmental } \\
\text { characteristic }\end{array}$ & $\begin{array}{c}\text { Witwatersrand Geological } \\
\text { System }\end{array}$ & $\begin{array}{c}\text { Ventersdorp Geological } \\
\text { System }\end{array}$ \\
\hline Altitude $(\mathrm{m})$ & $1601-1791$ & $1653-1784$ \\
Land type & $\mathrm{lb} 42$ & $\mathrm{lb} 43$ \\
Soil type & Mispah & Glenrosa \\
Soil depth $(\mathrm{mm})$ & $30-280$ & $70-320$ \\
Clay $(\%)$ & $<10$ & $35-40$ \\
Soil texture & Sandy & Clayloam \\
Rock cover $(\%)$ & $46-60$ & $31-45$ \\
Rock size & Boulders (>1000 mm) & Large rocks (>250 mm-1000 mm) \\
Terrain units & Scarp and mid-slope & Mid-slope \\
Aspect & South facing & South facing \\
Slope & Moderate to steep & Moderate \\
Slope $\left({ }^{\circ}\right)$ & $8-28$ & $12-20$ \\
\hline
\end{tabular}

Source: R. Deysel, Magister Technologiae: Nature Conservation Thesis, 2016

Terblanche et al. (2003), they are dominated by graminoids and forbs, with a variety of these flowering during the early and late growing seasons (Table 1).

Species richness in the habitats of the Witwatersrand and the Ventersdorp Geological Systems in the early and late growing seasons (Table 1) is similar to species richness recorded in other studies in grasslands (9-49 species per $\left.100 \mathrm{~m}^{2}\right)$ in Mucina and Rutherford (2006) and in Van Wyk (2003) (30-50 species per $100 \mathrm{~m}^{2}$ ). The vegetation study of Deutschländer and Bredenkamp (1999) revealed 13-20 plant species per sample plot $\left(100 \mathrm{~m}^{2}\right)$ in the habitat of the Roodepoort Opal Butterfly, Aloeides dentatis dentatis Swierstra, 1909 in the
Ruimsig Entomological Reserve. Edge, Cilliers and Terblanche (2008) recorded 42-49 plant species per sample plot $\left(25 \mathrm{~m}^{2}\right)$ during the vegetation surveys of the Brenton Blue Butterfly, Orachrysops niobe (Trimen 1862).

The C. pulchella var. pulchella densities (mean of 0.31 plants per square metre) recorded during the study of Terblanche et al. (2003) and observations made by Henning and Roos (1999) are similar to the densities recorded during this study. Clutia pulchella var. pulchella, recorded in all the habitats in both the early and late growing seasons, was one of the dominant forbs in the late growing season (Tables 3 and 4).

The topography and soil characteristics of the habitats and the shade from rocks may influence individual heights of C. pulchella var. pulchella and may explain the taller plants of this species in the Witwatersrand Geological System. None of the dominant forbs or dwarf shrubs that were recorded in these habitats exceeded $1000 \mathrm{~mm}$ in height. Similar results were obtained in a previous study on selected habitats conducted by Terblanche et al. (2003).

\section{Environmental characteristics}

The habitats of $C$. aureus are found on rocky, moderate to steep, south-facing mid-slopes dominated by the high occurrence of large surface rocks with crevices (Table 5). The study of Terblanche et al. (2003) and observations made by Henning and Roos (1999) indicated that C. aureus colonies were located 
in habitats where large surface rocks were present as it seemed to be a habitat requirement for the host plant, C. pulchella var. pulchella. The differences in soil depth, clay percentage and rock cover could give rise to the notable difference in the species composition and structure of the vegetation within the different habitats of the two geological systems.

\section{Presence and absence of the Heidelberg Opal Butterfly}

Chrysoritis aureus is localised in all the habitats where it occurs and individuals will mostly fly within a habitat range of $200 \mathrm{~m}^{2}-400 \mathrm{~m}^{2}$ (Terblanche \& Van Hamburg 2003) between 08:00 and 15:00 if the weather is moderate with no wind or clouds, at a height of $300 \mathrm{~mm}-700 \mathrm{~mm}$ above the grass and small bushes that grow between the rocks. Not observing butterflies at a specific habitat could be because of less favourable weather conditions on the day of recording (Cormont et al. 2011; Ide 2010). The ants are small and not easy to observe in these rocky habitats. It is possible that the ants were not observed in some habitats at the times of the field surveys because of them not being active and visible on the rocks in the sample plots or they were attending to the butterfly larvae and/or pupae in the rock crevices. All the larval stages, as well as the pupae of $C$. aureus are constantly attended by at least two C. liengmei ants (Terblanche \& Van Hamburg 2004).

\section{Conclusions}

Graminoids, forbs and dwarf shrubs dominated the vegetation structure of all habitats. The current ratios between these different growth forms need to be maintained and managed to ensure habitat suitability for $C$. aureus. The food plant was recorded in all the known habitats of C. aureus.

Chrysoritis aureus depends on a variety of habitat features for their survival. Habitat features include south facing rocky mid-slopes with large rocks and rock crevices, the presence of C. pulchella var. pulchella as larval food plant, a diversity of flowering forbs as a source of nectar for the butterfly and the presence of their host ants, C. liengmei. Without these equally important features in the habitats, $C$. aureus will not be able to complete its life cycle.

\section{Management}

Chrysoritis aureus has a low tolerance to any physical stress and is therefore highly sensitive to disturbances in its habitat (Henning \& Roos 1999). Typical disturbances would include too frequent fire events such as annual accidental fires and the establishment of alien invader plants. Specific objectives and actions in the protected area's management plans may be required as is currently performed for Alice Glöckner and Suikerbosrand Nature Reserves (Department of Agriculture and Rural Development 2012a, 2012b).

The following management actions in known habitats and adjacent areas should be considered to ensure the conservation of $C$. aureus:
- Monitoring of the C. aureus butterfly populations (butterfly, egg and larva numbers) and the butterfly's response after fire (direct and indirect).

- The existence of other suitable sites as butterfly habitats should be investigated, using the habitat details described here.

- Monitoring of the vegetation structure, species composition and growth forms to determine the vegetation condition and trends in habitat persistence, possible habitat degradation or habitat improvement after planed fires (McGeoch et al. 2011).

- The floristic characteristics, namely species richness, percentage canopy cover, dominant species, key species and density of the host plant, measured during this study should be used as baseline data for future vegetation condition comparisons. Monitoring surveys could be carried out every $3-4$ years. The response of the vegetation to the burning programme should be monitored and the burning programme adapted when and where necessary. It is suggested that the vegetation structure in the habitats of the Witwatersrand Geological System be managed and monitored to allow the percentage canopy cover of dwarf shrubs, graminoids and forbs to fluctuate between the upper and lower recorded percentages of $1 \%-12 \%$ (dwarf shrubs), $23 \%-57 \%$ (graminoids) and $1 \%-20 \%$ (forbs), respectively. Similarly, for the habitats of the Ventersdorp Geological System, the mean percentage canopy cover should be managed for dwarf shrubs, graminoids and forbs, to fluctuate between $2 \%$ and $6 \%$ (dwarf shrubs), $30 \%-75 \%$ (graminoids) and $8 \%-16 \%$ (forbs), respectively (these cover percentages vary from the lowest to highest values recorded for the habitats).

- The regular burning of habitats is required to maintain suitable vegetation composition and structure in these habitats for C. aureus. It is recommended that the habitats be burned each on a rotational quadrennial basis in the winter months when the butterfly is hibernating as a pupae in rock crevices.

- The occurrence of alien invader plants (especially trees) could indirectly affect the microclimate at the butterfly habitats or disturb the movement of individual butterflies between colonies (Henning \& Roos 1999; Terblanche et al. 2003). The spread of declared invader plants (wattles) in the vicinity of the butterfly habitats must be monitored. The removal of the declared invader tree species through recognised mechanical methods and herbicide application techniques is necessary.

The most important aspect of butterfly conservation is the quality and persistence of a species' habitat and its ability to maintain gene flow between populations (Henning et al. 2009). Proactive efforts to manage the vegetation composition and structure might ensure the persistence of suitable forb and graminoid-dominated habitats and, in turn, ensure the persistence and ultimately the survival of the endangered C. aureus. 


\section{Acknowledgements}

The authors would like to thank Tshwane University of Technology for financial assistance and the Gauteng Department of Agriculture and Rural Development for other resources and staff time during this study. The authors also thank Obeid Katumba, Natalie Horn, Sipho Ngoza, Obakeng Babuseng and Matimba Baloyi for their assistance and hard work during field surveys. Thanks to the SANDF, Heidelberg Kloof and the private land owners of Malanskraal for allowing field staff access to their properties during this study.

\section{Competing interests}

The authors declare that they have no financial or personal relationships which may have inappropriately influenced them in writing this article.

\section{Authors' contributions}

R.D. conducted all field surveys for Magister Technologiae, captured data and prepared the draft. W.J.M. and M.D.P. (both promotor and co-promotor on MTech, respectively) were involved from initial project proposal and planning through to the final thesis.

\section{References}

Barbour, M.G., Burk, J.H., Pitts, W.D., Gilliam, F.S. \& Schwartz, M.W., 1999, Terrestria plant ecology, 3rd edn., Addison Wesley Longman, Menlo Park, CA.

Braun-Blanquet, J., 1965, Plant sociology: The study of plant communities, transl. G.D. Fuller \& H.S. Conrad, Hafner Publishing Company, New York.

Bredenkamp, G.J., 1975, "n Plantsosiologiese studie van die Suikerbosrand Natuurreservaat', MSc thesis, University of Pretoria, Pretoria.

Bredenkamp, G.J. \& Van Rooyen, N., 1996, 'Moist cool Highveld grassland', in A.B. Low \& A.G. Rebelo (eds.), Vegetation of South Africa, Lesotho and Swaziland, p. 43, Department of Environmental Affairs \& Tourism, Pretoria.

Bromilow, C., 2001, Problem plants of South Africa, Briza Publications, Pretoria.

Coetzee, J.P., Bredenkamp, G.J. \& Van Rooyen, N., 1995, 'The phytosociology of the grassveld of the $\mathrm{Ba}$ and $\mathrm{Ib}$ land types in the Pretoria-Witbank-Heidelberg area', South African Journal of Botany 61(3), 123-133. https://doi.org/10.1016/S0254 6299(15)30498-1

Cormont, A., Malinowska, A.H., Kostenko, O., Radchuk, V., Hemerik, L., Wallisdevries, M.F. et al., 2011, 'Effect of local weather on butterfly flight behaviour, movement and colonization: Significance for dispersal under climate change', Biodiversity Conservation 20, 483-503.

Department of Agriculture and Rural Development, 2012a, 'Integrated management plan Alice Glöckner Nature Reserve 2012-2016', Directorate Nature Conservation, Johannesburg, Unpublished Report.

Department of Agriculture and Rural Development, 2012b, 'Integrated management plan Suikerbosrand Nature Reserve 2012-2016', Directorate Nature Conservation, Johannesburg, Unpublished Report.

Department of Agriculture and Rural Development, 2013, 'The vegetation classification of Alice Glöckner Nature Reserve', Technological Services, Directorate Nature Conservation, Johannesburg, Unpublished Report.

Deutschländer, M.S. \& Bredenkamp, G.J., 1999, 'Importance of vegetation analysis in the conservation management of the endangered butterfly Aloeides dentatis (Swierstra) (Lepidoptera, Lycaenidae)', Koedoe 42(2), 1-12. https://doi. org/10.4102/koedoe.v42i2.229

Edge, D.A., Cilliers, S.S. \& Terblanche, R.F, 2008, 'Vegetation associated with the occurrence of the Brenton blue butterfly', South African Journal of Science 104, 505-510. https://doi.org/10.1590/S0038-23532008000600028

Forestry Commission, 1996, Terrain classification, Technical Note 16/95:1-6, Technical Development Branch, Forestry Commission, UK, viewed 30 September 2015, from http://www.biomassenergycentre.org.uk/pls/portal/docs/PAGE/BEC http://wWw.biomassenergycentre.org.uk/pls/portal/docs/PAGE/BEC WOODFUEL\%20AND\%20TIMBER/HARVESTING/MANAGING\%20HARVESTING/ WOODFUEL\%20AND\%20TIMBER/HARVESTING/N

Germishuizen, G., Meyer, N.L., Steenkamp, Y. \& Keith, M. (eds.), 2006, A checklist of South African plants, Southern African Botanical Diversity Network Report No. 41, SABONET, Pretoria.
Henning, G.A. \& Roos, P.S., 1999, The conservation status of the Heidelberg Copper Butterfly (Poecilmitis aureus) in the Heidelberg district, Research report for Gauteng Provincial Government, Government Tender No. HK04/98, Unpublished Gauten
Report.

Henning, G.A. \& Roos, P.S., 1998, The conservation status of the Heidelberg Copper Butterfly (Poecilmitis aureus) in the Heidelberg district, Research report for Gauteng Provincial Government, Government Tender No. HK04/98, Unpublished Report.

Henning, G.A., Terblanche, R.F. \& Ball, J.B. (eds.), 2009, South African Red Data Book: Butterflies. SANBI Biodiversity Series 13, South African National Biodiversity Institute, Pretoria.

Hoare, D.B., 2006, Scale classification of extended lands of Suikerbosrand Nature Reserve, South Africa, Gauteng Department of Agriculture, Conservation, Environment and Land Affairs, Nature Conservation Division, Unpublished Report.

Ide, J., 2010, 'Weather factors affecting the male mate-locating tactics of the small copper butterfly (Lepidoptera: Lycaenidae)', European Journal of Entomology 107, 369-376.

Kent, M. \& Coker, P., 2003, Vegetation description and analysis, a practical approach, Wiley, New York.

Land Type Series, 1985, Land Type Map 2628 East Rand, Department of Agriculture and Water Supply, Government Printer, Pretoria.

Land Type Survey Personnel, 1985, Land Types of the Map 2628 East Rand and 2630 Mbabane, Memoir of the Agricultural Natural Resources of Southern Africa, No. 5 , Department of Agriculture and Water Supply, Pretoria.

Loxton, R.F., 1966, A simplified soil survey procedure for farm planning, Scientific Bulletin of the Department of Agricultural Technical Services 383, Government Printer, Pretoria.

Macvicar, C.N., Loxton, R.F., Lambrechts, J.J.N., Le Roux, J., De Villiers, J.M., Verster, E. et al., 1991, Grondklassifikasie, 'n Binomiese sisteem vir Suid-Afrika, Departement Landboutegniesedienste, Pretoria.

McGeoch, M.A., Sithole, H., Samways, M.J., Simaika, J.P., Pryke, J.S., Picker, M. et al., 2011, 'Conservation and monitoring of invertebrates in terrestrial protected areas', Koedoe 53(2), 1-13. https://doi.org/10.4102/koedoe.v53i2.1000

Mecenero, S., Ball, J.B., Edge, D.A., Hamer, M.L., Henning, G.A., Krüger, M. et al. (eds.), 2013, Conservation assessment of butterflies of South Africa, Lesotho and Swaziland: Red List and atlas, Saftronics (pty) Ltd., Johannesburg.

Mucina, L. \& Rutherford, M.C. (eds.), 2006, The vegetation of South Africa, Lesotho and Swaziland. Strelitzia 1, South African National Biodiversity Institute, Pretoria.

Myburgh, W.J., 2000, 'Die ekologie en plantegroeibestuur van die Olifantsriviersisteem', $\mathrm{PhD}$ thesis, University of Pretoria, Pretoria.

Panagos, M., 1999, A scale phytophysiognomic classification of the Suikerbosrand Nature Reserve, Agricultural Research Council - Range and Forage Institute, Pretoria.

Panagos, M.D., Westfall, R.H., Van Staaden, J.M. \& Zacharias, P.J.K., 1998, 'The plant communities of the Roodeplaat Experimental Farm, Gauteng, South Africa and the importance of classification verification', South African Journal of Botany 64(1), 44-61. https://doi.org/10.1016/S0254-6299(15)30826-7

Pooley, E., 2003, Mountain flowers, a field guide to the flora of the Drakensberg and Lesotho, The Flora Publication Trust, Durban.

Pooley, E., 2005, A field guide to wild flowers Kwazulu-Natal and the Eastern Region, The Flora Publication Trust, Durban.

Roos, P.S. \& Henning, G.A., 1998, The conservation status of the Heidelberg Copper Butterfly (Poecilmitis aureus) in the Heidelberg district (Lepidoptera: Lycaenidea: Aphnaeinae: Poecilmitis aureus van Son), Gauteng Department of Agriculture, Conservation and Environment, Gauteng, Unpublished Report.

Roos, P.S. \& Henning, G.A., 1999, The conservation status of the Heidelberg Copper Butterfly (Poecilmitis aureus) in the Heidelberg district (Lepidoptera: Lycaenidea: Aphnaeinae), Gauteng Department of Agriculture, Conservation and Environment, Gauteng, Unpublished Report.

SAPPI, 2004, Tree farming guidelines for private growers, Part 3 - Forest engineering, Chapter 7: Terrain classification, 2nd edn., viewed 06 August 2014, from http://www. sappi.com/regions/sa/SappiSouthernAfrica/Sappi\%20Forests/Pages/Tree-FarmingGuidelines.aspx or http://www.sappi.com/regions/sa/SappiSouthernAfrica/Sappi\% 20Forests/Tree\%20Farming\%20Guidelines/Part \%203_Forest $\% 20$ Engineering Chapter\%207 Terrain\%20Classification.pdf.

South African Weather Service, 2013, Climate information, Erasmusrand, Pretoria.

Terblanche, R.F., Morgenthal, T.L. \& Cilliers, S.S., 2003, 'The vegetation of three localities of the threatened butterfly species Chrysoritis aureus (Lepidoptera: Lycaenidae)', Koedoe 46(1), 73-90. https://doi.org/10.4102/koedoe.v46i1.44

Terblanche, R.F. \& Van Hamburg, H., 2004, 'The application of life history information to the conservation management of Chrysoritis butterflies (Lepidoptera: Lycaenidae) in South Africa', Koedoe 47(1), 55-65. https://doi.org/10.4102/ koedoe.v47i1.75

Terblanche, R.F. \& Van Hamburg, H., 2003, 'The taxonomy, biogeography and conservation of the myrmecophilous Chrysoritis butterflies (Lepidoptera: Lycaenidae) in South Africa', Koedoe 46(2), 65-81. https://doi.org/10.4102/ koedoe.v46i2.69

Van Oudtshoorn, F., 2004, Guide to grasses of Southern Africa, Briza Publications, Pretoria.

Van Wyk, B., 2003, Southern African Grasslands: Aspects of their biodiversity, dynamics and management, A presentation delivered at the Timber Plantations: Impact, Future Visions and Global Trends conference, Nelspruit, South Africa, November 11, 2003. 
Van Wyk, B. \& Malan, S., 1998, Field guide to the wild flowers of the Highveld, Struik Publishers, Cape Town

Werger, M.J.A., 1974, 'On concepts and techniques applied in the Zürich-Montpellier method of vegetation survey', Bothalia 11(3), 309-323. https://doi.org/10.4102/ abc.v11i3.1477

Westfall, R.H., Dednam, G., Van Rooyen, N. \& Theron, G.K., 1982, 'Phytotab - A programme package for Braun-Blanquet tables', Vegetatio 49, 35-37. https://doi. org/10.1007/BF00051562
Westfall, R.H. \& Panagos, M.D., 1988, 'The Plant Number Scale - An improved method of cover estimation using variable-sized belt transects', Bothalia 18(2), 289-291. https://doi.org/10.4102/abc.v18i1.1051

Westfall, R.H., Theron, G.K. \& Van Rooyn, N., 1997, 'Objective classification and analysis of vegetation', Plant Ecology 132, 137-154. https://doi.org/ 10.1023/A:1009746217097

Westfall, R.H., Van Staaden, J.M., Panagos, M.D., Breytenbach, P.J.J. \& Greef, A., 1996 Scale-related vegetation sampling, Agricultural Research Council - Range and Forage Institute Pretoria. 